\title{
Foliar anatomy and micromorphology of southern South American Alstroemeriaceae: Alstroemerieae, and its systematic implications in Alstroemeria
}

\author{
A. Mariel Sanso, Lone Aagesen and Cecilia C. Xifreda
}

A. M. Sanso (msanso@vet.unicen.edu.ar) and L. Aagesen, Consejo Nacional de Investigaciones Cientificas y Técnicas (CONICET), Argentina. AMS also at: Fac. Cs. Veterinarias, Univ. Nacional del Centro de la Provincia de Buenos Aires, Campus Univ., Paraje Arroyo Seco s/n, 7000 Tandil, Argentina. LA also at: Inst. de Botánica Darwinion, Labarden 200, C. C. 22, B1642HYD San Isidro, Argentina. - C. C. Xifreda, LEBA, Fac. Cs. Naturales y Museo, Univ. Nacional de La Plata, Calle 64 no. 3, 1900 La Plata, Argentina.

\begin{abstract}
Alstroemerieae is an exclusively Central and South American tribe belonging to Alstroemeriaceae, which comprises two large genera, Alstroemeria and Bomarea. Alstroemeria has two areas of distribution, mediterranean Chile and central southeastern Brazil. Most Bomarea species grow in forests and hedges in moist areas, however, some species are adapted to dry Andean valleys and high altitudes. Previous leaf anatomical data were obtained from a limited group of species. To assess the value of the anatomical characters for the systematics and their importance as adaptations to different environments, we compared representative species from different geographical areas and habitats. Data regarding leaf anatomy and micromorphology were obtained from light microscopy and scanning electron microscopy and were combined with macromorphology for 27 Alstroemerieae species. In accordance with earlier studies, our results show variation in relation to several leaf morpho-anatomical characters. Based on these we define seven types. We furthermore analyzed the morpho-anatomical characters in a phylogenetic context. Morpho-anatomical characters are highly homoplastic within the family. Leaf anatomy may support monophyly of Baker's informal grouping of Alstroemeria Brazilian species with rigid leaves, however, a more thorough study of Brazilian Alstroemeria species are needed to confirm this.
\end{abstract}

An update of the Angiosperm Phylogeny Group classification (APG III 2009) considers Alstroemeriaceae Dumort. to include two tribes, Alstroemerieae Bernh. and Luzuriageae Benth. \& Hook. The first one is an exclusively Central and South American tribe, which comprises two large genera, Alstroemeria L., including Schickendantzia Pax and Taltalia Ehr. Bayer, (ca 70 species) and Bomarea Mirb. (ca 120 species), including Leontochir Phil. Alstroemerieae species are long lived, perennial herbs, with the exception of A. graminea Phil., which was reported as annual by Bayer (1998). Alstroemerieae species have terminal umbel-like inflorescences, rarely unifloral, showy flowers, and thickened roots modified to store nutrients and water (Sanso and Xifreda 2001). Additionally, nearly all members of the tribe have resupinate leaves: the leaves are twisted near the base or along the lamina, placing the morphological adaxial surface as the functional lower surface. According to Napp-Zinn (1974), the inverse dorsiventrality in leaves of Alstroemeria pelegrina L. raised the attention of Treviranus as early as 1835 . Some of the earlier descriptions of leaf anatomy of Alstroemerieae species (formerly Alstroemeriaceae) are those of Haberlandt (1882) and Dufour (1886) on Alstroemeria psittacina Lehm.; Colozza (1898, 1901) and Schulze (1893) studied species of Bomarea and Alstroemeria; Scharf (1892), Goebel (1913) Bomarea; Kugler (1928) and Arber (1925) A. aurea Graham (=A. aurantiaca D. Don), and finally Sanso and Xifreda (1995) B. edulis (Tuss.) Herb. The most recent studies were made by Sanso and Xifreda (1998), by Lyshede (2002), mainly on Chilean Alstroemeria species and by Hofreiter and Lyshede (2006), mostly on Peruvian species of Bomarea.

The genus Alstroemeria has two main areas of distribution: Chile and central southeastern Brazil. Whereas Lyshede (l. c.) focused on twelve species from Chile, the present study includes Alstroemeria species from both geographical areas. The sister genus Bomarea is mainly distributed in the Andean mountains between Colombia and Bolivia with most species found in forests and hedges in moist areas (Hofreiter and Tillich 2002). However, some species of Bomarea subgenus Wichuraea are adapted to dry Andean valleys and high altitudes (Hofreiter and Tillich 2003). The present study includes representative species from these 
geographical areas to examine the value of leaf anatomical and morphological characters for the systematics and the adaptations to different environments.

One of the first attempts to make an infrageneric Alstroemeria classification was published by Baker (1888), who distinguished two major groups: the Chilean and the Brazilian species. Further, in each of these two groups, the species were divided according to the leaf texture and morphology. This author (l. c.) circumscribed as an informal group twelve Brazilian Alstroemeria species with rigid leaves. On the other hand, Assis in her thesis (2001) divided the Brazilian species into 4 informal groups, three of these (groups 1-3) including species with more or less rigid leaves, but differentiated by presence or absence of fibres associated with the vascular bundles.

Phylogenetic studies based on DNA sequence data (Aagesen and Sanso 2003, Chacón et al. 2012) have confirmed the monophyly of Alstroemeria and Bomarea but failed to provide detailed resolution at subgeneric level. For this reason, an additional goal for us was to explore whether the morpho-anatomical foliar characteristics include qualitative traits that may contribute to resolve phylogenetic relationships within the genera.

\section{Material and methods}

\section{Taxon sampling}

Fully grown leaves were collected in the field. Those of Chilean origin were obtained from plants cultivated at the Copenhagen Botanical Garden (Denmark). When it was not possible to obtain living material, samples were taken from herbarium specimens.

In the anatomical analysis 23 Alstroemeria taxa, including A. graminea and A. pygmaea (previously included in the monotypic genera Taltalia and Schickendantzia) and 11 Bomarea species (including B. ovallei) were used. The studied taxa and their provenance are shown in the Table 1. For macromorphological considerations, observations made by Bayer (1987), Sanso and Xifreda (1995), Sanso (1996), Assis (2001), and Aagesen and Sanso (2003) were also taken into account.

\section{Scanning electron microscopy}

SEM of leaves were carried out at the SEM Service of La Plata Museum, Argentina. Lamina samples were mounted

Table 1. Taxa and origin of plant material used in this study. ${ }^{*}=$ only SEM data; $+=$ species analyzed for the first time.

\begin{tabular}{|c|c|c|}
\hline Taxon & Origin & Voucher \\
\hline Alstroemeria andina Phil. subsp. andina*+ & Chile & Castillo w/n (SGO 100086) \\
\hline Alstroemeria andina Phil. subsp. venustula (Phil.) M. Muñoz+ & Argentina & Kiesling $9062(\mathrm{SI})$, Fortunato and Kiesling 5630 (BAB) \\
\hline Alstroemeria angustifolia Herb. subsp. angustifolia & Chile & Cult. Copenhagen Botanical Garden P1995-5003 (SI) \\
\hline Alstroemeria apertiflora Baker + & Paraguay & Hassler 5811, $10099(\mathrm{G})$ \\
\hline Alstroemeria aurea Graham & Argentina & Xifreda and Sanso 2015, $2030($ SI) \\
\hline Alstroemeria exserens Meyen & Chile & Cult. Copenhagen Botanical Garden P1995-5009 (SI) \\
\hline Alstroemeria graminea Phil.*+ & Chile & von Bohlen 1275 (SGO 131118) \\
\hline Alstroemeria hookeri Lodd. subsp. hookeri & Chile & Cult. Copenhagen Botanical Garden P1995-5010 (SI) \\
\hline Alstroemeria isabellana Herb. + & Argentina & Sanso et al. 5 (SI) \\
\hline Alstroemeria ligtu L. subsp. ligtu & Chile & Cult. Copenhagen Botanical Garden P1995-5026 (SI) \\
\hline Alstroemeria magnifica Herb. subsp. magnifica & Chile & Cult. Copenhagen Botanical Garden P1995-5013 (SI) \\
\hline Alstroemeria pallida Graham & Chile & Cult. Copenhagen Botanical Garden P1995-5034 (SI) \\
\hline Alstroemeria patagonica Phil.+ & Argentina & Xifreda and Sanso 2035 (SI) \\
\hline Alstroemeria pelegrina $\mathrm{L}$. & Chile & Garaventa 3262, $4196(\mathrm{SI})$ \\
\hline Alstroemeria presliana Herb. subsp. presliana & Argentina & Xifreda and Sanso 2012 (SI) \\
\hline Alstroemeria pseudospathulata Ehr. Bayer+ & Argentina & Xifreda and Sanso 2004 (SI) \\
\hline Alstroemeria psittacina Lehm. & Argentina & Cult. FCEN, University of Buenos Aires (SI) \\
\hline Alstroemeria pulchra Sims subsp. pulchra & Chile & Cult. Copenhagen Botanical Garden P1995-5046 (SI) \\
\hline Alstroemeria pygmaea Herb. + & Argentina & Sanso and Pereyra 8 (SI) \\
\hline Alstroemeria revoluta Ruiz \& Pav.+ & Chile & Cult. Copenhagen Botanical Garden P1995-5049 (SI) \\
\hline Alstroemeria sellowiana Seub.+ & Brazil & Kummron 3357 (ESA) \\
\hline Alstroemeria versicolor Ruiz \&. Pav. & Chile & Cult. Copenhagen Botanical Garden P1995-5052 (SI) \\
\hline Alstroemeria werdermanii Ehr. Bayer+ & Chile & Cult. Copenhagen Botanical Garden P1995-5054 (SI) \\
\hline Bomarea andimarcana (Herb.) Baker & Peru & Sanso and Pereyra 26, Sanso and Pereyra 27 (SI) \\
\hline Bomarea boliviensis Baker+ & Argentina & Cult. Hunziker 22 (SI) \\
\hline Bomarea dulcis (Hook.) Beauverd & Peru & Sanso and Pereyra 21 (SI) \\
\hline Bomarea edulis (Tuss.) Herb.+ & Argentina & Xifreda and Sanso 867, Sanso and Pereyra 9 (SI) \\
\hline Bomarea glaucescens (H.B.V.) Baker*+ & Ecuador & Lehmann $499(\mathrm{~K})$ \\
\hline Bomarea macrocephala Pax+ & Argentina & Sanso and Pereyra $11(\mathrm{SI})$ \\
\hline Bomarea ovallei (Phil.) Ravenna & Chile & Macaya Berti (w/n) (SI), Ricardo w/n (SGO 73065) \\
\hline Bomarea ovata (Cav.) Mirb.+ & Peru & Sanso and Pereyra $22(\mathrm{SI})$ \\
\hline Bomarea salsilla (L.) Herb.*+ & Chile & Silva w/n (SGO 104724) \\
\hline Bomarea setacea (Ruiz \& Pav.) Herb.* & Colombia & Hunziker 11407 (SI) \\
\hline Bomarea stans Kraenz.*+ & Argentina & Kiesling et al. $3767(\mathrm{SI})$ \\
\hline
\end{tabular}


onto SEM stubs using double-sided adhesive tape, coated with gold using a Jeol JFC-1100 ion sputter coater and subsequently examinated in a Jeol JSM-T100 SEM.

\section{Light microscopy}

Material for LM were fixed in 3\% glutaraldehyde in $0.25 \mathrm{M}$ phosphate buffer ( $\mathrm{pH}$ 6.8) for $24 \mathrm{~h}$, dehydrated in a graded ethanol series and acetone for $2 \mathrm{~h}$ in each step and embedded in Spurr's resin. Transverse sections (TS) of leaf laminas of $1 \mu \mathrm{m}$ or $2 \mu \mathrm{m}$ thickness were stained with Toluidine blue (O'Brien and McCully 1981), as metachromatic stain and Ruthenium red (Luft 1971). Epidermal samples were stripped from the leaf, stained with Toluidine blue and mounted in glycerol jelly.

\section{Phylogeny}

Selected qualitative morpho-anatomical characters analysed in the present study (Appendix 1) were added to the DNA sequence data set published by Chacón et al. (2012). Species for which voucher material was lacking were coded according to information found in the literature, mainly Assis $(2001,2009)$. We extracted sequences of $m a t K$, matR, $n d h F$, and $r b c L$ from GenBank (<www.ncbi.nlm.nih.gov>) (Supplementary material Appendix A1). The matrix was assembled with the program GB-to-TNT (Goloboff and Catalano 2012) calling Mafft for the alignment step (Katoh and Toh 2008). The combined matrix was analyzed in TNT ver. 1.1 (Goloboff et al. 2003), searching for the most parsimonious trees and branch supports with gaps coded as missing data.

\section{Results}

\section{Micromorphology}

Epidermal features observed with SEM showed variation in relation to the pubescence, cell shape, sinuosity of anticlinal cell walls, orientation pattern and type of wax particles. In particular, regarding this last point, new data were obtained for Bomarea species.

Alstroemerieae leaves are glabrous or with indumenta, sometimes trichomes on the ribs (Fig. 1A). Midvein protruding adaxially, but in some species, ribs protruding on both surfaces (Fig. 1B). In paradermal view, adaxial cells longitudinally elongated (Fig. 1C) or intercostal ones asymmetrical, like a jigsaw puzzle (Fig. 1D), and with more wax than those on the abaxial surface, with or without sinuous anticlinal walls (Fig. 1E). Stomata are anomocytic in parallel rows (Fig. 1F). Abaxial cells are more or less rectangular with straight or undulating anticlinal walls.

Distinctive epicuticular waxes form parallel rows of longitudinally aligned platelets, in regular (Fig. 1G) or, occasionally random orientation (Fig. $1 \mathrm{H}-\mathrm{I}$ ), in characteristic patterns around the stomata, sometimes, radiating around them (Fig. 2A). Wax particles of different shapes and sizes, from flakes to filaments and granules. In some species the two surfaces have different types of wax (A. pygmaea, A. patagonica); adaxial epidermis with a granular, warty layer
(Fig. 2B); in other ones, warty coating composed of crustlike particles (B. stans, Fig. 2C), dense wax deposit, consisting of rods or threads randomly orientated and superimposing (B. salsilla, Fig. 2D), irregular scales arranged in upright angles with random orientation (B. setacea, Fig. 2E) or, concave, plate-like wax with cuticle areas free of wax (B. dulcis, Fig. 2F).

Stomatal guard cells are with wax particles (Fig. 2A) but in A. magnifica subsp. magnifica, without them. Stomatal rim raised, aperture long and narrow (Fig. 2G). Stomata slightly sunken and surrounded by curved ridges of cuticle on the subsidiary cells (Fig. 2C) but in species as those of the Brazilian group, the curved ridges are not outstanding (Fig. 2G-H).

\section{Anatomy}

\section{Resupination}

Leaf anatomy is inverted, in nearly all Alstroemerieae species, with stomata and indument, when present on only one side, at the morphological adaxial surface (indicated by the position of vascular tissues in TS). In species having stomata on both surfaces, the pattern is recognizable by the protuberance of main nerves or the hooded apex, both characters for the adaxial surface.

\section{Lamina thickness}

Lamina thickness between midrib and margin in crosssection ranges from 100 (A. psittacina, 4 mesophyll cell layers) to $620 \mu \mathrm{m}$ ( $A$. andina subsp. venustula, 9-10 layers). The thickest lamina was observed in $A$. andina subsp. venustula, A. patagonica, A. pseudospathulata and $A$. werdermannii.

\section{Epidermis}

Single cell layer. In Alstromeria adaxial and abaxial epidermal cells are of equal height, except in $A$. pelegrina (Fig. 4G) and $A$. pulchra. In most Bomarea species, the abaxial epidermis is more developed. Adaxial cells are generally taller above the midrib (Fig. 5H), and in extreme cases, distinctly large above vascular bundles partly hiding intercostal areas (Fig. 4G); cell walls of variable thickness, with irregular or smooth borders. Abaxial outer cell walls are thickened; in Bomarea subg. Wichuraea, very thick and convex, whereas adaxial outer cell walls are relatively thin (Fig. $3 \mathrm{H}$ ).

Anomocytic stomata. In Bomarea generally restricted to the adaxial side; in Alstroemeria, on both surfaces (amphistomatic leaves, $A$. andina subsp. venustula, $A$. patagonica), but fewer stomata on the abaxial surface or only on the adaxial. More or less sunken stomata, except in $A$. psittacina (Fig. $4 \mathrm{H}$ ), with an outer cuticular rim and thick-walled guard cells (Fig. 3A) or minute/absent outer and inner rim with very thick-walled stomatal apparatus cells (Fig. 3B). In Bomarea each pair of guard cells is surrounded by subsidiary cells, very thick cuticular ridges, as hood-like projections on the guard cells, in the boundary with the ostiole; cuticular layer continued on the inner tangential walls, in contact with a very wide substomatic chamber.

\section{Mesophyll distribution}

Dorsiventral laminas in all investigated species of Bomarea and most Alstroemeria taxa, but in some Chilean-Argentinian 

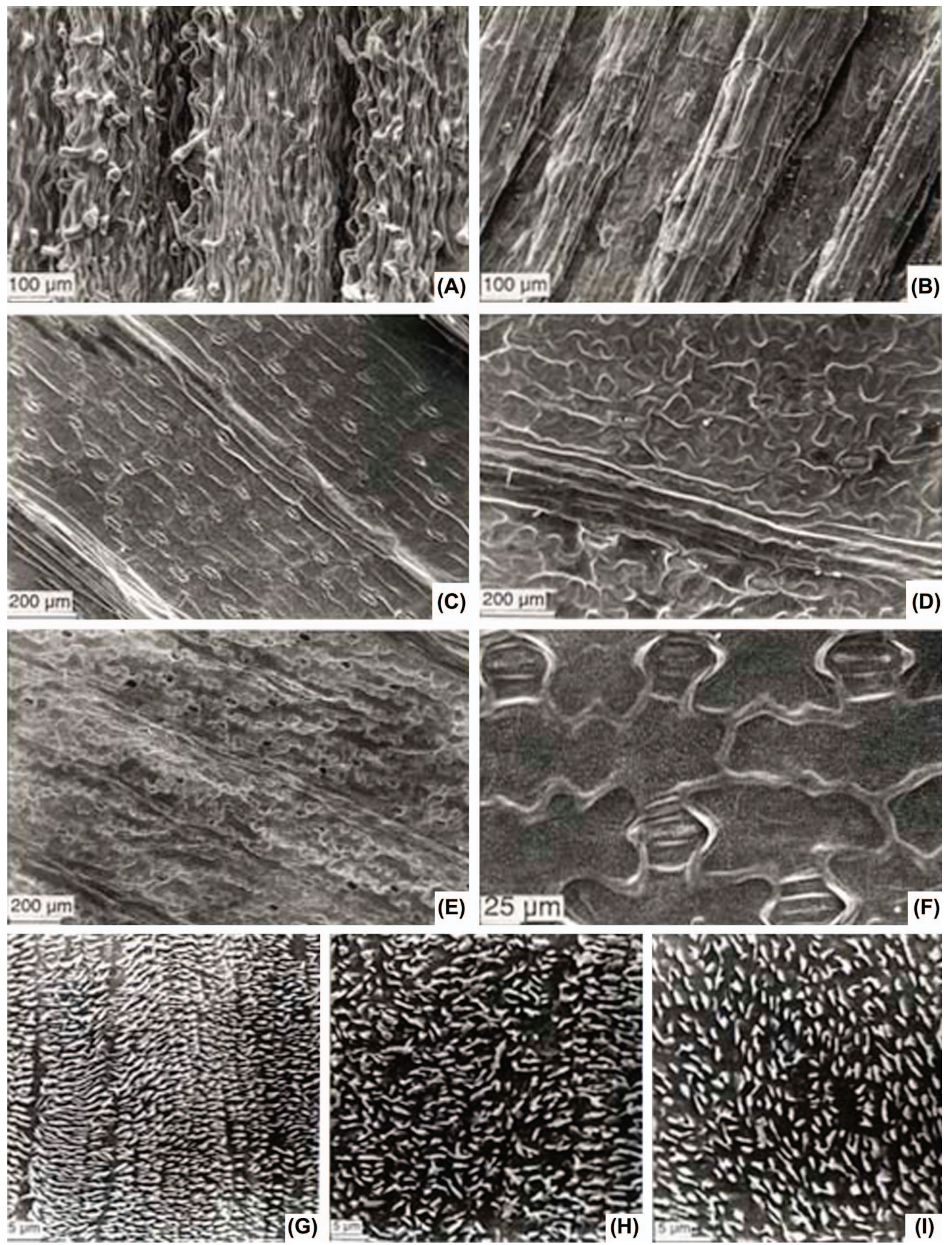

Figure 1. Micromorphological characters in Alstroemerieae. Surface cells and waxes. Electron micrographs (SEM). (A)-(B) B. macrocephala; (A) adaxial surface, trichomes abundantly distributed mostly on leaf ribs; (B) abaxial surface, glabrous and with veins protruding also on this leaf surface. (C) $A$. isabellana, abaxial cells arranged in paralleled rows. (D) -(E) cell walls with undulating outline, (D) A. psittacina, (E) A. aurea. (F) B. stans, anomocytic stomata arranged in paralleled rows. (G) A. revoluta, short wax striations with regular orientation. (H)-(I) wax platelets with random orientation. (H) A. ligtu subsp. ligtu, (I) A. magnifica subsp. magnifica. 

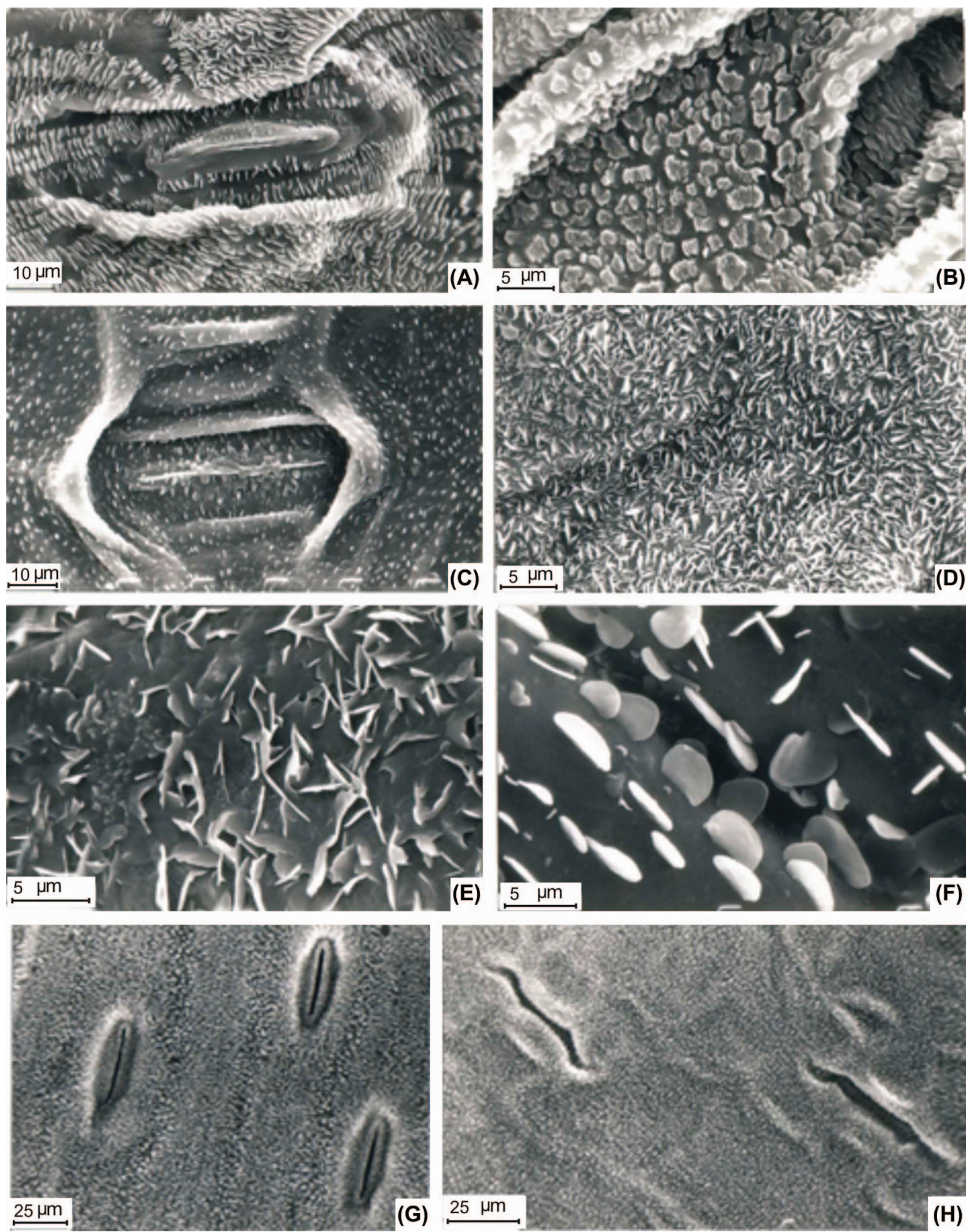

Figure 2. Micromorphological characters in Alstroemerieae. Wax arrangement pattern. Electron micrographs (SEM). (A) B. macrocephala, wax particles in characteristic pattern, radiating around the stoma. (B) A. pygmaea, adaxial surface with granular warty layer. (C) B. stans, sunken stoma with crustose wax particles. (D) B. salsilla, dense wax deposit consisting in rods or threads randomly orientated. (E) B. setacea, irregular scales arranged in upright angles with random orientation. (F) B. dulcis, concave plate-like particles. (G) A. apertiflora, stomata almost superficial without curved ridges. $(\mathrm{H})$ A. isabellana, sunken stomata without curved ridges. 

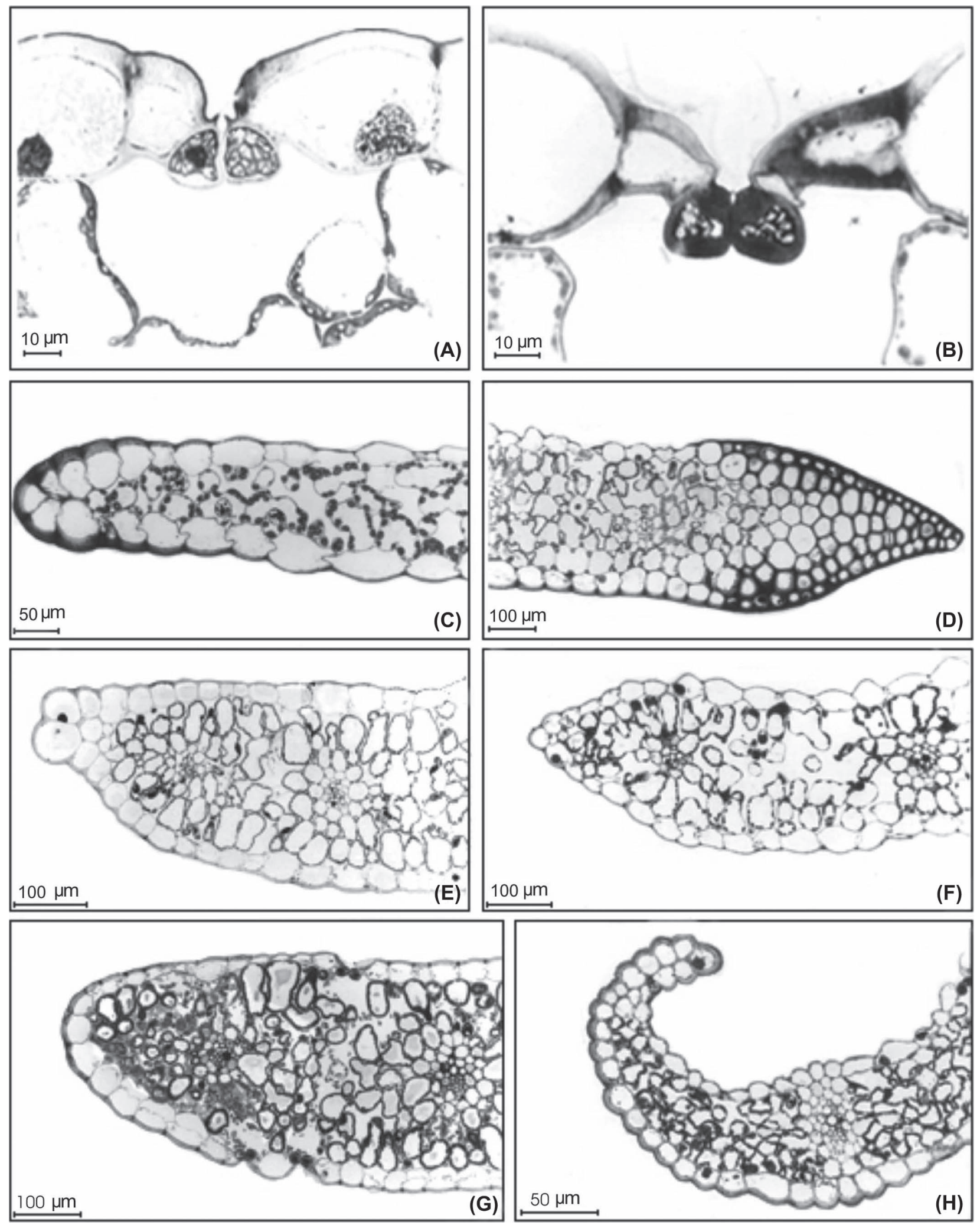

Figure 3. Stomata and leaf margin in Alstroemerieae. TS at light microscopy. (A) A. isabellana. stoma with outer cuticular rim and guard cells with thick walls. (B) $A$. andina subsp. venustula, stoma with minute outer rim cuticular ridges and very thickened walled stomatal apparatus cells. (C) A psittacina, rounded margin with around 9 to10 cells of the apex presenting outer cell walls thickened. (D) A. isabellana, fusiform margin, edges thickened with one to two layer of around 20 smaller and schlerenchymatous cells occurring on both epidermis sides. (E) A. angustifolia subsp. angustifolia, leaf margin blunty shaped by tiers of two or three large cells. (F) A. hookeri subsp. hookeri, blunty shaped apex. $(\mathrm{G})$ A. versicolor, rounded margin. $(\mathrm{H})$ B. macrocephala, involute leaf margin finishing in two and finally one cell. 

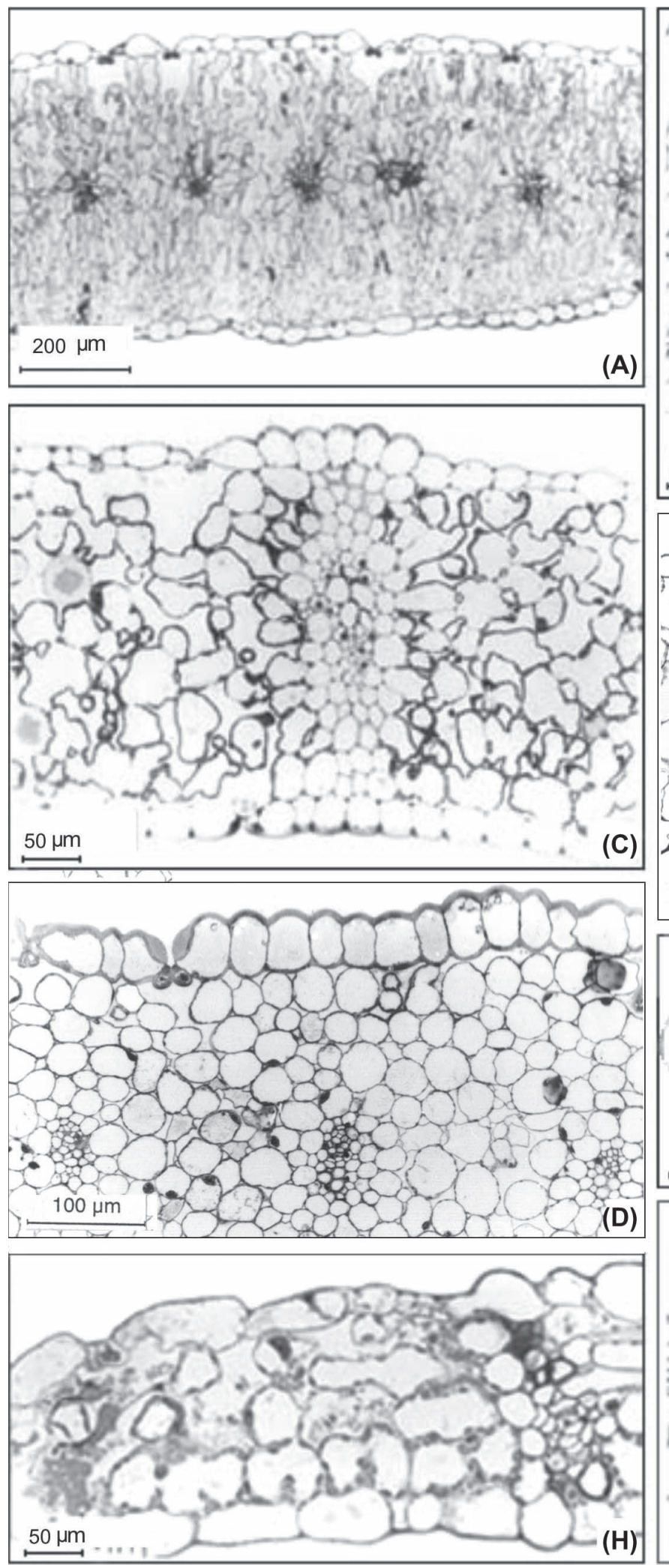
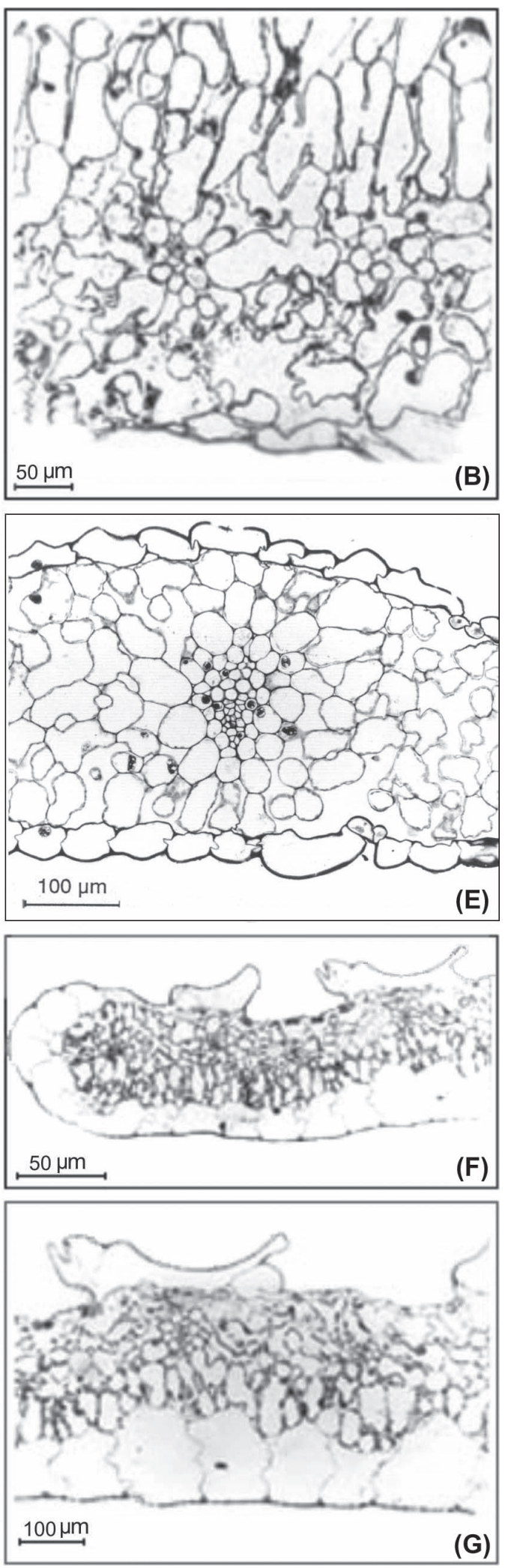

Figure 4. Morpho-anatomical types in Alstroemerieae. TS at light microscopy. (A) A. andina subsp. venustula, slightly dorsiventral and wide lamina. (B) A. pseudospathulata, mesophyll with conspicuos lobed cells. (C) A pygmaea, chlorenchyma with cells fairly irregular in shape. (D) A. patagonica, rather compact chlorenchyma tissue, composed of small, isodiametric cells and a vascular bundle. (E) A. isabellana, mesophyll poorly differentiate with cells irregularly shaped and large intercellular spaces. (F)-(G) A. pelegrina, dorsiventral lamina with one layered palisade mesophyll contiguous the abaxial surface. (G) adaxial surface with extremely large epidermal cells on the vascular bundle. (H) A. psittacina, thin mesophyll with one palisade layer occurring beneath the abaxial surface, some of these cells bone-like shaped. 
ones, such as $A$. patagonica, and some Brazilian species with rigid leaves, such as $A$. isabellana, the mesophyll is only slightly differentiated; in $A$. patagonica tightly packed, circular to oval, thin-walled cells and abundant chloroplasts with mostly small, triangular intercellular spaces were observed (Fig. 4D); in A. isabellana mesophyll not compact, irregularly shaped cells with rather conspicuous intercellular spaces (Fig. 4C). Palisade cells rectangular, as in A. hookeri subsp. hookeri (Fig. 5C), or multi-lobed, as in A. psittacina (Fig. 4H). In $A$. pseudospathulata, arrangement of the mesophyll basically bifacial, tending to an intermediate condition, with the addition of discontinuos palisade on the abaxial side (Fig. 4B). Cells of spongy parenchyma difficult to distinguish from the palisade ones, irregularly shaped and vertically oriented, nevertheless, on the phloem side, cells less lobed and more closely packed.

\section{Vascular tissue}

Closed vascular bundles, oval in shape, collateral, organized centrally in the mesophyll as a single row, and usually surrounded by a distinct parenchymatous sheath. In $A$. andina subsp. venustula, sheath with elongated cells radially arranged (Fig. 4A); in Bomarea (Fig. 5G) and Alstroemeria Brazilian taxa (Fig. 4C), associated with sclerenchyma.

\section{Leaf margin}

Leaves dorsiventrally flattened, with rounded (Fig. 3C) to acute margins (Fig. 3D). In A. psittacina, rounded margin, 9-10 cells with thickened outer walls; in A. isabellana, fusiform margin, with edges thickened and stramineous, 1-2 layers of about 20 cells, one smaller and sclerenchymatous (Fig. 3D); in A. angustifolia subsp. angustifolia (Fig. 3E) and A. hookeri subsp. hookeri (Fig. 3F), margins blunt and shaped by tiers of 2-3 large cells; in $A$. ligtu, A. pelegrina, A. exserens and $A$. versicolor (Fig. 3G), rounded margins; in $B$. edulis, cells with thickened outer and lateral walls and in B. macrocephala, involute margins (Fig. $3 \mathrm{H}$ ), cuticle thicker in the margin, with the epidermal cells often distinctly domed.

\section{Indument}

Alstroemeria leaves generally glabrous but sometimes with papillae covering the whole surface (adaxial surface of $A$. andina subsp. venustula), only the margins or the apex (some Brazilian Alstroemeria species with rigid leaves, $A$. apertiflora, $A$. isabellana, A. sellowiana). Bomarea leaves with or without hairs (B. ovallei, B. salsilla), finely pubescent (B. boliviensis, B. edulis, B. macrocephala) to densely pilose ( $B$. dulcis, $B$. ovata), trichomes hyaline, unbranched, uniseriate, uni- to multi-cellular, 1-4 to 10-celled.

\section{Morpho-anatomical types}

Seven morpho-anatomical types based on leaf characters were defined in accordance with the studied material. Major histological features of these types are described below.

1) Alstroemeria andina group. A. andina subsp. venustula (Fig. 4A), A. pseudospathulata (Fig. 4B), A. werdermanii

Very thick leaves, maximum intercostal width from 400 (A. pseudospathulata) to $620 \mu \mathrm{m}$ (A. andina subsp. venustula) or $800 \mu \mathrm{m}$ in vascular bundles (A. pseudospathulata). Epidermal cells elongated along the leaf short axis or isodiametric $(30-40 \mu \mathrm{m})$. Cuticle thick to very thick (A. pseudospathulata, $10 \mu \mathrm{m})$ on both surfaces. Stomata sunken to deeply sunken ( $A$. andina subsp. venustula), almost exclusively or more densely distributed on the xylem side and smaller or absent on the other surface. Papillae on adaxial surface in $A$. andina subsp. venustula. Laminas slightly dorsiventral, with conspicuously lobed cells in the mesophyll (8-9 layers).

\section{2) A. isabellana group. A. isabellana (Fig. 4C), A. apertiflora, A. sellowiana}

Leaves coriaceous. Lamina thickness from 300 to $420 \mu \mathrm{m}$, or ca $520 \mu \mathrm{m}$ in the main vascular bundle (A. isabellana); thinner lamina in $A$. apertiflora, $160-180 \mu \mathrm{m}$. Abaxial epidermal cells isodiametric $(30-40 \mu \mathrm{m})$; adaxial, less regular in size and larger on the midrib. Cuticle thin. Stomata on both surfaces, but more numerous on the adaxial one. Mesophyll only slightly differentiated into palisade (one layer on abaxial side) and spongy parenchyma, with cells irregularly shaped and large intercellular spaces. Sclerenchyma surrounding the vascular bundles, as girders from the vascular bundle sheaths towards both epidermises, except in some minor ones.

\section{3) A. patagonica group. A. patagonica (Fig. 4D), A. pygmaea (Fig. 4E)}

Laminas equifacial, without differentiation between palisade and spongy mesophyll. Epidermal cells of both sides equal in size; sunken stomata, less frequent on abaxial side. Cuticle thick in A. patagonica, less so in A. pygmaea. Chlorenchyma tissue rather compact and composed of small, isodiametric cells (A. patagonica, 9-13 layers) or of fairly irregular cells, with intercellular spaces (A. pygmaea, 5-6 layers). Mechanical tissues absent.

\section{4) A. pelegrina group. A. pelegrina (Fig. 4F-G), A. pulchra} Laminas dorsiventral, one-layered palisade mesophyll contiguous on the abaxial surface, with thin spongy mesophyll (4-5 layers). Abaxial epidermis with large cells, uniform in size (60-70 $\mu \mathrm{m}$ heigh), without stomata. Adaxial epidermis with flat cells in the intercostals areas; above veins characteristically thin walled, free of chloroplasts; bulliform cells (Fig. 4G), in A. pelegrina, 10-15 times larger than the rest of the epidermal cells $(50-60 \mu \mathrm{m}$ height). Stomata slightly sunken.

5) A. psittacina group. A. psittacina (Fig. $4 \mathrm{H})$, A. angustifolia subsp. angustifolia, A. aurea (Fig. 5A), A. exserens Fig. 5B), A. hookeri subsp. hookeri (Fig. 5C), A ligtu subsp. ligtu, A. magnifica subsp. magnifica, A. pallida, A. presliana subsp. presliana, A. revoluta, A. versicolor (Fig. 5D)

Leaves membranaceous, widest in $A$. angustifolia subsp. angustifolia and $A$. versicolor; thinnest in $A$. psittacina $(100-150 \mu \mathrm{m})$. Mesophyll of 3-7 layers, one cell layer regular and lined up contiguously to one or both epidermises. In $A$. psittacina, a palisade layer towards abaxial epidermis with bone shape-like cells and high density of chloroplasts (Fig. 4H). Spongy mesophyll with rounded and irregular cells and intercellular spaces, quite dense (A. revolute) or with 

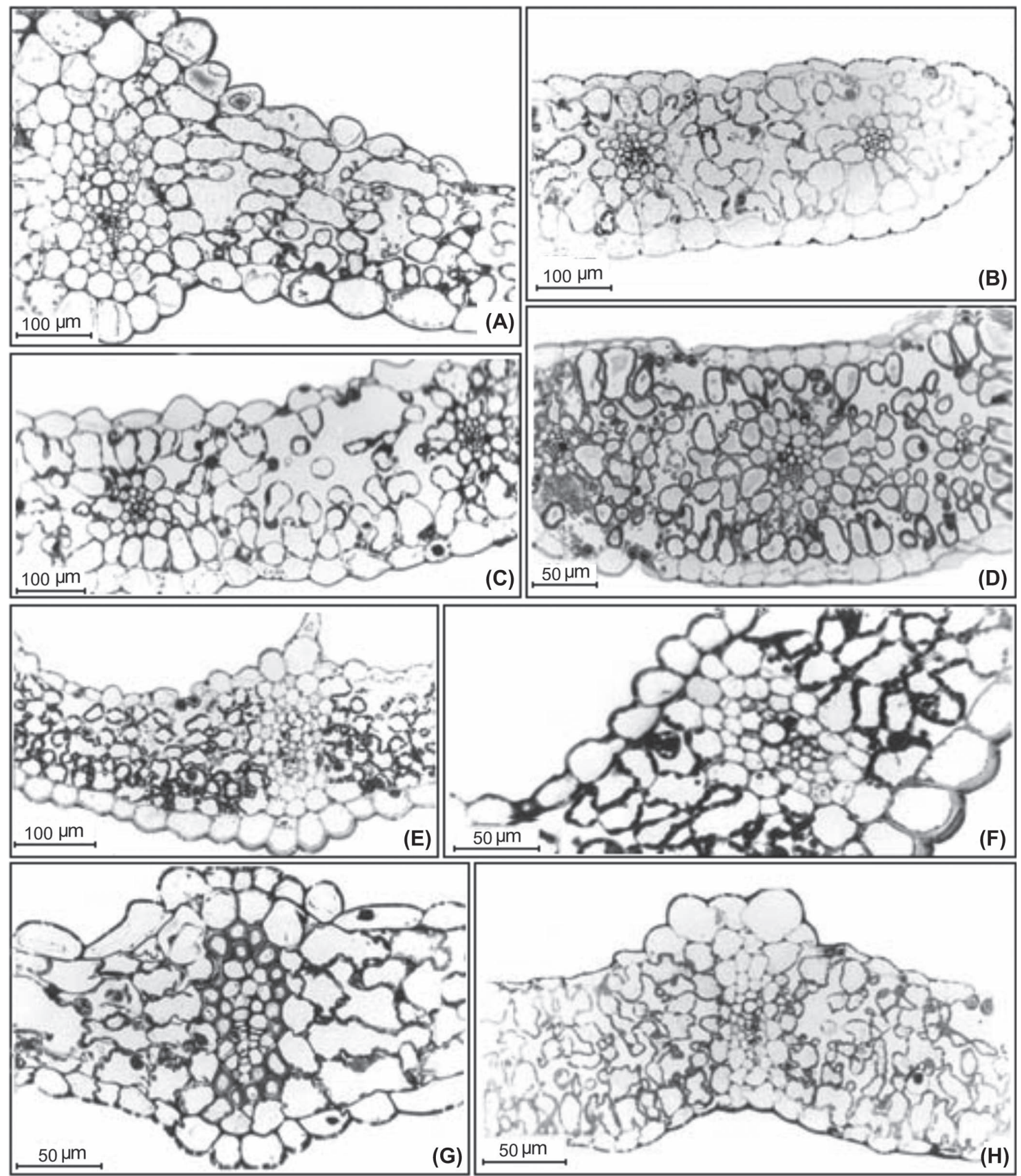

Figure 5. Morpho-anatomical types in Alstroemerieae. TS at light microscopy. (A) A. aurea, on the left, midrib with larger epidermal cells above it. (B) A. exserens, mesophyll slightly dorsiventral and conspicuous intercellular spaces. (C) A. hookeri subsp. hookeri, mesophyll with important intercellular spaces. (D) A. versicolor, some mesophyll cells regular and lined up contiguos to each epidermis side and remaining ones, isodiametric and irregularly distributed. (E) - (F) B. macrocephala, dorsiventral lamina, the adaxial surface with sunken stomata and a trichome. (F) detail of a vascular bundle; abaxial surface with thick cuticle. (G) B. edulis, principal vascular bundle surrounded by a schlerenchymatous sheath. (H) B. boliviensis, slightly dorsiventral lamina showing the principal vascular bundle with larger epidermal cells above it. 
more intercellular spaces (A. aurea, A. hookeri subsp. hookeri (Fig. 5A, C). Sunken stomata on both/adaxial side or superficial stomata on one side (A. psittacina).

\section{6) Bomarea macrocephala group. B. macrocephala (Fig. 5E-F), B. andimarcana, B. dulcis}

Involute and dorsiventral laminas. Epidermal cells elongated along the short axis of the leaf, with undulating anticlinal walls, larger on the veins. Adaxial surface pubescent, with sunken stomata; abaxial, glabrous or pubescent; trichomes more abundant on the veins (Fig. 5E), very thick cuticle, paradermal cell walls thickened (up to $14 \mu \mathrm{m}$ ) (Fig. 5F). Mesophyll of 5-10 layers, maximum width $300 \mu \mathrm{m}$ (B. andimarcana); cells arrangement more compact on the phloem side, forming a palisade layer. Sclerenchymatous sheaths composed of one or several cell layers.

\section{7) B. edulis group. B. edulis (Fig. 5G), B. boliviensis (Fig. 5H), B. ovallei}

Laminas equifacial or slightly dorsiventral, from 210 (B. edulis) to $320 \mu \mathrm{m}$ (B. ovallei) or $600 \mu \mathrm{m}$ in the major vascular bundle (B. boliviensis). Epidermal cells with thin cuticle, and slightly sunken stomata on adaxial side. Spongy mesophyll with rounded or irregular cells (4-5 layers) and intercellular spaces; palisade mesophyll contiguous to the abaxial epidermis, of bone-like or lobed cells (Fig. $5 \mathrm{H}$ ). Vascular bundles surrounded by parenchymatous sheaths, the larger bundle, by sclerenchymatous cells.

\section{Phylogeny and taxonomical considerations}

The qualitative morpho-anatomical character matrix is found in Supplementary material Appendix A2. Note, only species for which DNA sequence data was available could be included in the phylogenetic analysis, hence Alstroemeria pulchra and Bomarea andimarcana were excluded. The final matrix included 119 taxa and 13 morphoanatomical characters. The combined data set yielded more than 10000 optimal trees (length $=1021, \mathrm{CI}=0.71$ ). Figure 6 shows a selected optimal tree with branch support and branches that are collapsed in the strict consensus tree. With the present species sampling available for morpho-anatomical analyses the fraction of missing data is high, and the morpho-anatomical characters add limited structure at subgeneric level. None of the morpho-anatomical types formed monophyletic groups, and most characters may have evolved several times within the family. The Brazilian species with rigid leaf (species group I and III, Assis 2001) do not form a monophyletic group (Fig. 6). However, only species from group III were examined in the present study, and these were found to be monophyletic with the exception of $A$. longistyla (for which voucher material was not available). Presence of sclerenchyma in the vascular bundle sheaths (character 12) and sclerenchyma in bundle sheaths extended as girders from the vascular bundles towards both leaf surfaces (character 13) define the Brazilian species with rigid leaves. Both are well defined qualitative characters, which may show to support monophyly of the Brazilian species with rigid leaves (species group I + III) if coding of these characters are completed among the Brazilian Alstroemeria species.

\section{Discussion}

In this comparative study on representative species of the Alstroemeriaceae, Alstroemerieae showed variation in relation to several morpho-anatomical characters of the leaf, confirming previous results obtained mainly by Lyshede (2002), but also by Xifreda and Sanso (1998).

Papillae were found in few species of Alstroemeria; very inconspicuous ones at the apex in $A$. apertiflora, A. isabellana and A. sellowiana, and more visible ones in the trans-Andean $A$. andina subsp. venustula. According to Assis (2001) other Brazilian species with papillae are: A. foliosa, A. speciosa and A. viridiflora. On the contrary, trichomes are widespread in Bomarea.

The epicuticular wax arrangement and the orientation of parallel platelets found in most of the studied species have been described as 'Convallaria-type' (Barthlott and Frolich 1983). Flat crystalloids with entire margin and regular shape, 'Entire platelets type' (Barthlott et al. 1998) were exclusively found in some Bomarea species, e.g. B. dulcis. Epicuticular wax may appear with an upright orientation or in different angles from $0^{\circ}$ to $90^{\circ}$. Orientation and distribution of the particles modify the capacity to scatter light. Also, contrary to traditional thoughts, the cuticle's thickness and overall wax load do not control water evaporation. Instead, thick cuticles probably play a much more general, structural, and protective role (Kerstiens 1996).

Leaf anatomy and epicuticular wax of the B. setacea complex were studied by Hofreiter (2006). Some differences found between his and our results, such as the lack of epicuticular wax in both leaf surfaces (Hofreiter 1. c., Hofreiter and Lyshede 2006) or the presence of irregular scales arranged in upright angles (this paper), may be the consequence of his more narrow species.

Amphistomatous leaves are frequently associated with plants growing under dry conditions, but the primary relationship is probably with increased leaf thickness, for reasons concerned with optimized gas exchange under water stress (Parkhurst 1978). Correlated with this, the thickest laminas among the studied species have developed in parallel in $A$. andina subsp. venustula, which inhabits stony or sandy slopes of the Andean mountains, A. patagonica and A. pseudospathulata from the Patagonian meseta, and A. werdermannii from the Atacama desert, all environments with pronounced water shortage.

Bulliform cells are larger than the typical epidermal cells, thin-walled, and with a large vacuole, placed only on the veins. They were observed in 'A. pelegrina-type' species and previously by Lyshede (l. c.) but without using the present denomination. Similarly, Rudall (1994) described a small groups of enlarged, bulliform cells in distinct regions of the leaf epidermis, or over larger vascular bundles in Iridaceae. As pointed out by Fahn (1990) they may have a functional significance in relation to the involution of leaves, a characteristic of xerophytes, as result of their loss or uptake of water by hydrostatic movements.

The palisade mesophyll commonly comprises round cells, but sometimes presents deeply lobed cells appearing branched ( $A$. andina subsp. venustula), or with intermediate forms (A. psittacina). Rudall et al. (1986) recorded them in 


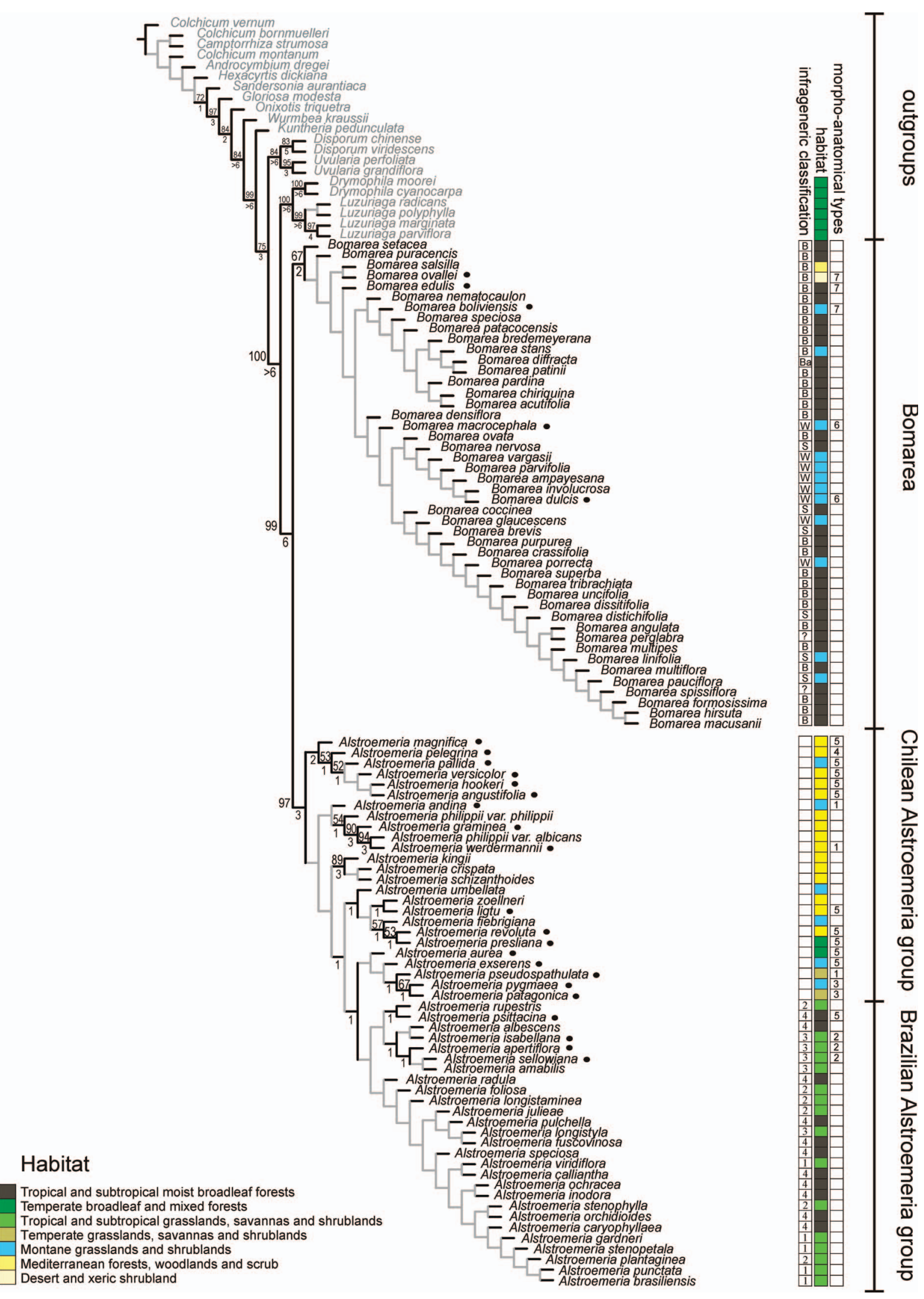

Figure 6. A selected optimal tree. The numbers above the branches are jackknife values from 10000 replicates, those below the branches are Bremer supports. Grey branches are collapsed in the strict consensus tree. The numbers in the column showing infrageneric divisions refer to formal and informal divisions discussed in the text. The numbers in the column showing morpho-anatomical types refer to the grouping discussed in the text. Habitats are recorded for species in Alstroemeriaceae, following the biomes of Olson et al. (2001). 
Sisyrinchium (Iridaceae) and considered that the adaptive advantages of this mesophyll type were unknown. However, Fahn (1990), supposed that shape and arrangement of these specialized mesophyll cells increase the internal surface area of the leaf and could results in a more efficient photosynthesis.

Neither A. pygmaea, A. graminea nor B. ovallei present unique foliar character states. Thus, to all existing arguments for not retaining Schickendantzia, Taltalia nor Leontochir as separate genera (Sanso and Xifreda 1999, 2001, Sanso 2002, Aagesen and Sanso 2003), we can add the morpho-anatomical foliar group of characters.

Our data would support the group including species of Bomarea subgenus Wichuraea ('Bomarea macrocephalatype'). However, phylogenetic analyses based on DNA sequence data (Fig. 6 and Alzate et al. 2008, Chacón et al. 2012) do no recover clades that represent the recognized subgenera of Bomarea (Baker 1888, Hofreiter and Tillich 2002). Bomarea subgenus Wichuraea species, have lanceolate to linear leaves that are sometimes small and closely appressed to the stem, ascending, marcescent at anthesis, with involute margins, which determine an adaxial funnel (kennel), and have a high degree of uniformity in relation with the leaf anatomy. All Wichuraea grow in full sun, only some of the climbing species may occur in light shadow inside the fog forests (Hofreiter and Tillich 2003) in high mountains. Perhaps as a consequence of habitat, this group presents leaf features that might be regarded as xeromorphic according to Fahn and Cutler (1992), e.g. with a reduced leaf area, strongly involute margins, and on the adaxial epidermis with outer cell walls that are conspicuosly convex (domed) in transversal sections. The occurrence of sclerenchyma could also be interpreted as an adaptation to xeromorphy. However, this character needs to be interpreted with care in a broad survey of Bomarea species.

Assis (2001) assembled Brazilian species with rigid leaves and sclerenchyma in vascular bundles in two groups, the 'A. gardneri group' and the 'A. longistyla group' species, group I and III, respectively. With the present character coding leaf morpho-anatomical data do not support the monophyly of the Brazilian species group with rigid leaves (here the 'Alstroemeria isabellana-type'). However, only species from group III were examined in the present study. According to Assis (l. c) both groups have an extension of the sclerenchymatous sheaths, but the second group possess fewer fibres than the first. Coding presence of sclerenchyma in the vascular bundle sheath and extension of the sclerenchymatous sheaths (character 12 and 13) in all species of groups I and III proposed by Assis (2001) would render these groups monophyletic (results not shown). The species are distributed in marshy regions of the neotropical savannas (group III) and in the Cerrado (group I). According to the dated phylogeny in Chacón et al. (2012) the species with rigid leaves diverged from other Alstroemeria species less than 10 Ma years ago, towards the end of a phase of global cooling, in agreement with the estimated age of other Cerrado lineages (Simon et al. 2009). The distinctive anatomy in A. isabellana and other species from its group, showing hygromorphic characters (large intercellular spaces, spongy tissue, thin cuticle) and the conspicuous sclerenchyma distribution giving mechanical support to the leaf would be an adaptation to marshy regions, never fully drying, and wet 'campos' with tall grasses. These species form a monophyletic group (with exception of $A$. longistyla that was not examined in the present study). Among the other species groups mentioned by Assis (2001), group IV correspond to the 'A. psittacina' type in the present study, the leaf type that appears to be plesiomorphic within Alstroemeria (Fig. 6). Voucher material of species from group II was not available in the present study.

\section{Conclusions}

We analyzed morpho-anatomical characters from in a wide range of Alstroemeriaceae species from different geographic regions and different habitats. Our assessment allows to infer the value of the foliar anatomy and morphology as taxonomical characters in Alstroemeriaceae tribe Alstroemerieae and their systematic implications on subgeneric delimitation. Further studies to group the taxa with thin leaves in different taxonomical sections remain to be done, for example, the scanning in other species for bulliform cells such as those observed in A. pelegrina. A broader foliar anatomical survey, especially on more Brazilian species of Alstroemeria and species of Bomarea, may allow recognizing further phylogenetic relationships within the group.

Acknowledgements - We are grateful to Marcelo Girardi, Vladimiro Dudas, and Rafael Urréjola for technical assistance and to the reviewers for all suggestions. This work was supported by CONICET, UBA and CIC-PBA from Argentina.

\section{References}

Aagesen, L. and Sanso, A. M. 2003. The phylogeny of the Alstroemeriaceae based on morphology, rps16 intron and $r b c L$ sequence data. - Syst. Bot. 28: 47-69.

Alzate, F. et al. 2008. Phylogenetic analyses of Bomarea (Alstroemeriaceae) based on combined analyses of nrDNA ITS, $p$ sbA-trnH, rpoB-trn $C$ and matK sequences. - Taxon 57: 853-862.

APG III 2009. An update of the Angiosperm Phylogeny Group classification for the orders and families of flowering plants: APG III. - Bot. J. Linn. Soc. 161: 105-121.

Arber, A. 1925. Monocotyledons. A morphological study. - Cambridge Univ. Press.

Assis, M. C. 2001. Alstroemeria L. (Alstroemeriaceae) do Brasil. - PhD thesis, Univ. de São Paulo, Brasil.

Assis, M. C. 2009. New species of Alstroemeria (Alstroemeriaceae) from Brazil. - Novon 19: 145-149.

Baker, J. G. 1888. Handbook of the Amaryllideae. - George Bell and Sons, London.

Barthlott, W. and Frolich, D. 1983. Mikromorphologie und Orientierungsmuster epicuticularer Wachs-Kristalloide: ein neues systematisches Merkmal bei Monokotylen. - Plant Syst. Evol. 142: 171-185.

Barthlott, W. et al. 1998. Classification and terminology of plant epicuticular wax. - Bot. J. Linn. Soc. 126: 237-260.

Bayer, E. 1987. Die Gattung Alstroemeria in Chile. - Mitt. Bot. Staatssamml. München 24: 1-362.

Bayer, E. 1998. Taltalia - eine neue Gattung in der Familie der Alstroemeriaceae. - Sendtnera 5: 5-14. 
Chacón, J. et al. 2012. From east Gondwana to Central America: historical biogeography of the Alstroemeriaceae. - J. Biogeogr. 39: 1806-1818.

Colozza, A. 1898. Contributo all'anatomia delle Alstroemeriee. - Malpighia 12: 165-197.

Colozza, A. 1901. Nuova contribuzione all'anatomia delle Alstroemeriee. - Nuovo Giorn. Bot. Ital. 8: 477-491.

Dufour, L. 1886. Note sur les relations qui existent entre l'orientation des feuilles et leur structure anatomique. - Bull. Soc. Bot. France 33: 268-276.

Fahn, A. 1990. Plant anatomy. 4th ed. - Pergamon Press.

Fahn, A. and Cutler, D. F. 1992. Xerophytes. Vol. XII, 3 of Encyclopaedia of plant anatomy. - Gebrüder Bornträger.

Goebel, K. 1913. Organographie der Pflanzen 2, Aufl. Band 1. $-\mathrm{G}$. Fischer.

Goloboff, P. A. and Catalano, S. A. 2012. GB-to-TNT: facilitating creation of matrices from GenBank and diagnosis of results in TNT. - Cladistics 28: 503-513.

Goloboff, P. A. et al. 2003. Tree analysis using new technology, ver. 1.1. - < <ttp://www.zmuc.dk/public/phylogeny/ TNT $>$.

Haberlandt, G. 1882. Vergleichende Anatomie des assimilatorischen Gewebesystems der Pflanzen. - Jahrb. Wissen. Bot. 3: $74-188$.

Hofreiter, A. 2006. The Bomarea setacea complex (Alstroemeriaceae). - Harv. Paper Bot. 11: 39-52.

Hofreiter, A. and Lyshede, O. B. 2006. Functional leaf anatomy of Bomarea Mirb. (Alstroemeriaceae). - Bot. J. Linn. Soc. 152: 73-90.

Hofreiter, A. and Tillich, H.-J. 2002. The delimitation, infrageneric subdivision, ecology and distribution of Bomarea Mirbel (Alstroemeriaceae). - Feddes Repert. 113: 528-544.

Hofreiter, A. and Tillich, H.-J. 2003. Revision of the subgenus Wichuraea (M. Roemer) Baker of Bomarea Mirbel (Alstroemeriaceae). - Feddes Repert. 114: 208-239.

Katoh, K. and Toh, H. 2008. Recent developments in the MAFFT multiple sequence alignment program - Brief. Bioinform. 9: 286-298.

Kerstiens, G. 1996. Signalling across the divide: a wider perspective of cuticular structure-function relationships. - Trends Plant Sci. 1: 125-129.

Kugler, H. 1928. Über invers-dorsiventrale Blätter. - Planta 5: 89-134.

Luft, J. 1971. Ruthenium red and violet. II. Fine structural localization in animal tissues. - Anat. Record 171: 369-392.

Appendix 1. Qualitative morpho-anatomical character used in the phylogenetic analysis.

1. Leaves resupinate: no (0); yes (1). In nearly all species belonging to Alstroemerieae the leaves are resupinate making the adaxial surface as the functional lower surface.

2. Resupination of leaves: partial, twisting only some leaves (0); complete (1).

3. Surface of the functional abaxial side of the leaf: glabrous (0); with papillae (1); with hyaline hairs (2). The character has been coded as additive in the analyses as we consider the hyaline hairs to be prolonged papillae, hence state 1 and 2 are homologous and should be coded as internested states.

4. Papillae at the apex of the leaves: absent (0); present (1). In the Brazilian Alstroemeria species with stiff rigid leaves, inconspicuous papillae are found at the leaf apex. The character has also been coded as present in species having papillae covering the whole surface.
Lyshede, O. B. 2002. Comparative and functional leaf anatomy of selected Alstroemeriaceae of mainly Chilean origin. - Bot. J. Linn. Soc. 140: 261-272.

Napp-Zinn, K. 1974. Anatomie der Blattes. Blattanatomie der Angiospermen 2 A. - Gebrücher Bornträger, pp. 1030-1032.

O'Brien, T. and McCully, M. 1981. The study of plant structure, principles and selected methods. - Termarcarphi Pty, Melbourne.

Olson, D. M. et al. 2001. Terrestrial ecoregions of the world: a new map of life on earth: a new global map of terrestrial ecoregions provides an innovative tool for conserving biodiversity. - BioScience 51: 933-938.

Parkhurst, D. F. 1978. The adaptive significance of stomatal occurrence in one or both surfaces of leaves. - J. Plant Ecol. 66: 367-383.

Rudall, P. 1994. Anatomy and systematics of Iridaceae. - Bot. J. Linn. Soc. 114: 1-21.

Rudall, P. et al. 1986. An anatomical and chromosomal investigation of Sisyrinchium and allied genera. - Bot. Gaz. 147: 466-477.

Sanso, A. M. 1996. El género Alstroemeria (Alstroemeriaceae) en Argentina. - Darwiniana 34: 349-382.

Sanso, A. M. 2002. Chromosome studies in Andean taxa of Alstroemeria (Alstroemeriaceae). Bot. J. Linn. Soc. 138: 451-459.

Sanso, A. M. and Xifreda, C. C. 1995. El género Bomarea (Alstroemeriaceae) en Argentina. - Darwiniana 33: 315-336.

Sanso, A. M. and Xifreda, C. C. 1998. Comparative foliar anatomy in Alstroemeriaceae. - Monocots II, 2nd Int. Symp. Comp. Biol. Monocotyledons. Sydney, Australia. Abstracts, p. 82.

Sanso, A. M. and Xifreda, C. C. 1999. The synonymy of Schickedantzia with Alstroemeria (Alstroemeriaceae). - Syst. Geog. Plants 68: 315-323.

Sanso, A. M. and Xifreda, C. C. 2001. Generic delimitation between Alstroemeria and Bomarea (Alstroemeriaceae). - Ann. Bot. 38: 1057-1069.

Scharf, W. 1892. Beiträge zur Anatomie der Hypoxideen und einiger verwandter Pflanzen. - Beih. Bot. Centralbl. 52: 45-153.

Simon, M. F. et al. 2009. Recent assembly of the Cerrado, a neotropical plant diversity hotspot, by in situ evolution of adaptations to fire. - Proc. Natl Acad. Sci. USA 106: 20359-20364.

Schulze, R. 1893. Beiträge zur vergleichenden Anatomie der Liliaceen, Haemodoraceen, Hypoxidoideen und Velloziaceen. - Bot. Jahrb. 17: 295-394.
5. Cuticle thickness: thin (0); intermediate condition (1); thick (2). The character is coded additive.

6. Stomata present on both the adaxial and abaxial surface of the leaves: absent from abaxial surface (0); present on both surfaces (1).

7. Cells of both epidermises conspicuosly different in size: no (0); yes (1).

8. Bifacial lamina: no (0); yes (1).

9. Presence of lobed cells in the mesophyll: no (0); yes (1).

10. Lobed cells: some and not outstanding lobed (0); conspicuously lobed (1).

11. Conspicuosly distinct vascular bundle sheath: no (0); yes (1).

12. Sclerenchyma in vascular bundle sheath: no (0); yes (1).

13. Sclerenchyma in bundle sheaths extended as girders from the vascular bundles towards both leaf surfaces: no (0); yes (1). 